\title{
Impact of Integrated Fish Farming on Antimicrobial Resistant Bacteria in Pond Environments in Osun State, Nigeria
}

\author{
Bolaji A. Samuel, Magdalene C. Igboama* and I.I. Olufade \\ Department of Science Laboratory Technology, Federal Polytechnic Ede, Osun State, Nigeria \\ *Corresponding author
}

\begin{tabular}{|l|}
\hline Ke y w o r d s \\
Integrated, Fish \\
Farming, \\
Antimicrobial \\
Resistant, Impact, \\
Bacteria
\end{tabular}

\section{Introduction}

Integrated fish farming is a system of farming that combines livestock production with fish farming. The system utilizes animal excreta, urine and feed leftovers as pond substrates to enhance the growth of plankton and other microorganisms eaten by fish. In integrated fish farms, animal dung is shed into the fish pond as manure supporting the growth of plankton and other micro organisms eaten by fish thereby producing high yields of fish with low input as the fish receive limited supplementary feed. The livestock on the other hand are fed with feed containing antimicrobial agents which serve as growth promoters. It has the capacity of meeting up with fish demand as it supplies enough manure to produce large quantity of fish (Ayinla 2003). Integrated fish farming 
provides job opportunities to both the women and the teeming population of the youths in a country. In addition to the above, the system provides food security and raises nutritional status by providing important complementary ingredients for better nutrition.

The combination of fish and poultry or fish and piggery excreta have been found to fertilize the pond and are avenue for fish to derive their energy. The use of poultry in integrated fish farming has been found to be beneficial to the fishes because of the algal bloom produced which serves as food and hiding place for fishes (FAO, 2003). Pig and fish combination on the other hand increases both economic and ecological efficacy as aquatic plants, wastes, residues and left over from kitchen are used as Pig food while the excreta of the Pigs which is very rich in nutrients is used as organic manure and fish feed in ponds thereby greatly reducing the cost of fish production (AIFP. 2005).

The feed of the livestock mainly chickens and pigs contain antibiotics which are used for therapeutic or prophylactic purposes in integrated fish farms, These antimicrobial agents serve as growth promoters to fishes and prevent proliferation of bacteria in fish pond however bacteria that survive the antimicrobial agents become drug resistant serving as reservoirs of resistant genes from which genes can be disseminated to human pathogens (Ole et al., 2009). These antibiotic resistant bacteria (ARB) may be harbored on the skin, gut and slime of living fish which if consumed may cause infections in humans and result in treatment failures.

Information on the development of antimicrobial resistant strains of bacteria in fish ponds in Osun state, Nigeria is scarce hence the need for this study which is designed to investigate the impact of integrated fish farming on antimicrobial resistant bacteria in a pond environment.

\section{Materials and Methods}

All materials including media, glass wares and bench surfaces were adequately sterilized.

\section{Study area}

Integrated fish farms located at Mopo Ede, Mobi Ede and Ring road Osogbo, Osun state, Nigeria were accessed in this study after consent was obtained from the owners. Information on the type of feed given to the fish and livestock was obtained verbally from the managers of the ponds.

\section{Collection of samples}

A total number of four specimens from each farm site were collected. The samples were; Pond sediments, Pond water, Fish feeds ad Fish gut. The samples were transported to the laboratory for immediate analysis.

\section{Isolation of bacteria}

One gram of Pond sediments, Pond water, Fish feeds and Fish guts was accurately weighed out, ground and serially diluted. One milliliter of the aliquots from the dilution $10^{-5}$ of each sample was transferred into appropriately labeled petri dishes into which sterile MacConkey agar was poured and allowed to solidify. This was done in triplicates (Harley and Precott, 1996). The plates were incubated at $37^{\circ} \mathrm{C}$ for 24 hours after which developed colonies were counted to obtain total viable count followed by sub culturing. Pure cultures were stored at $4^{\circ} \mathrm{C}$ in slants of MacConkey agar.

\section{Characterization and identification of bacteria isolates}

The isolates were characterized and identified based on their cultural characteristics, grams stain and biochemical reactions. 


\section{Antibiotic susceptibility test}

The bacteria isolates were examined for susceptibility to commonly used antimicrobial agents using commercially available discs and following the manufacturers' instruction. The zones of inhibition were read after incubation and recorded as resistant or sensitive.

\section{Results and Discussion}

The average plate counts of samples from different location were significantly different as $\mathrm{P}<0.05$ for each of the locations. The bacterial count in Sawmill pond ranged from $5.0 \times 10^{6} \mathrm{Cfu} / \mathrm{ml}$ to $1.40 \times 10^{7} \mathrm{Cful} / \mathrm{ml}$. Also, in Mobi pond the bacteria counts ranged from $9.5 \times 10^{6} \mathrm{Cfu} / \mathrm{ml}$ to $2.92 \times 10^{7} \mathrm{Cfu} / \mathrm{ml}$ while the bacteria counts in Ring road had $9.1 \times 10^{6}$ $\mathrm{Cfu} / \mathrm{ml}$ to $2.27 \times 10^{7} \mathrm{Cfu} / \mathrm{ml}$ respectively. Pond sediments and water samples from Mobi pond had the highest bacterial counts and this was followed by those from fish pond water of Ring road and Sawmill respectively. The highest bacterial count was also recorded in Fish gut sample obtained from Sawmill pond water and this was followed by the higher bacterial count in Mobi and Ring road pond water respectively. Similarly, the highest bacterial count was recorded in Ring road pond followed by the least bacterial count in Mobi and Sawmill respectively (table 1).

A total of 48 bacteria isolates were gotten from four specimen types; Pond water, Pond sediment, Fish feed and Fish gut. Bacterial isolates identified were: Escherichia coli 7(14.58\%), Aeromonas species 5(10.41\%), Salmonella species $5(10.41 \%)$, Proteus species 4(8.33\%), Citrobacter freundii $3(6.25 \%)$, Morganella morganii 5(10.41\%), Enterobacter species 4(8.33\%), Serratia species 4(8.33), Klebsiella species 4(8.33\%), Provindencia species $3(6.25 \%)$ and Shigella species 2(4.16) (Table 3).
Escherichia coli, Aeromonas species and Serratia species, were the bacteria that occurred in all the four samples (Table 3). The bacteria isolates that occurred both in pond water and pond sediment were: Citrobacter freundii and Proteus species while only Shigella species were isolated from both fish gut and fish feed (Table 3).

Pond water had a total of 14 (29.2\%) bacteria isolates of which $4(8.33 \%)$ were from Ring road, $8(16.66 \%)$ bacteria isolates were from Mobi pond while 2(4.17\%) bacteria isolates were from Sawmill pond at the lowest proportion. Water sediment had a total of $14(29.2 \%)$ bacteria isolates of which 2(4.16\%), 9(18.7\%) and 3(6.25\%) were from Ring road, Mobi and Sawmill ponds respectively. Fish gut had a total of 11(22.9\%) bacteria isolates of which $5(10.41 \%)$ and $3(6.25 \%)$ bacteria isolates were from Mobi, Ring road and Sawmill ponds respectively.

A total of $9(18.7 \%)$ bacteria isolates were reported for Fish feed out of which 2(4.16\%) bacteria isolates were from Ring road, 4(8.33\%) from Mobi and 3(6.25\%) from Sawmill pond (Table 2).

The highest percentage of bacteria was observed to occur in water sediment sample. This could be as a result of accumulation of surplus feed overtime. Pond water sample was observed to be next in bacteria percentage. This could be because feed was applied to water over a period of time. Gut and feed samples had the lowest percentage of bacteria isolates. The reason could be because there was no accumulated effect in feeds and the feed which the fish ate had been mixed with water before entering the gut of the fish (Figure 1).

The result of the Antimicrobial Resistivity Test revealed that most of the isolated organisms were resistant to multiple 
antibiotics. The highest antimicrobial resistance of $93.33 \%$ was exhibited against Septrin and Chloramphenicol by 14 isolates while this was followed by a higher antimicrobial resistance of $66.67 \%$ against
Augumentin by 5 isolates. The lowest antimicrobial resistance of $6.67 \%$ was obtained for 1 isolate against Ciprofloxacin (table 4).

Table.1 Average bacterial count of isolates from the samples

\begin{tabular}{lll}
\hline $\begin{array}{l}\text { LOCATION } \\
\text { ERROR }\end{array}$ & CODE & MCA WITH STANDARD \\
\hline EDE SAWMILL & ESS & $8.2 \times 10^{6} \pm 20.43$ \\
& ESW & $5.0 \times 10^{6} \pm 5.77$ \\
ESF & $1.35 \times 10^{7} \pm 20.82$ \\
EDE MOBI & ESG & $1.40 \times 10^{7} \pm 7.94$ \\
& EMS & $2.92 \times 10^{7} \pm 5.13$ \\
EMW & $1.81 \times 10^{7} \pm 18.01$ \\
OSOGBO RING ROAD & EMF & $9.5 \times 10^{5} \pm 18.93$ \\
& EMG & $1.00 \times 10^{7} \pm 17.56$ \\
& ORS & $2.27 \times 10^{7} \pm 22.86$ \\
& ORW & $1.46 \times 10^{7} \pm 17.06$ \\
& ORF & $1.60 \times 10^{7} \pm 10.41$ \\
& ORG & $9.1 \times 10^{6} \pm 10.41$ \\
\hline
\end{tabular}

Key:

ESS -Ede Sawmill Sediment

ORS - Osogbo Ringroad Sediment

ESF - Ede Sawmill Feed

ESW - Ede Sawmill Water

ORG - Osogbo Ringroad Gut

ESG - Ede Sawmill Gut

ORW - Osogbo Ringroad Water

EMF - Ede Mobi Feed

ORF - Osogbo Ringroad Feed

EMW - Ede Mobi Water

EMS - Ede Mobi Sediment

EMG - Ede Mobi Gut

Table.2 Percentage bacteria in different locations

\begin{tabular}{|lccc|}
\hline Location & Ring road & Mobi & Sawmill \\
\hline Pond water & $4(15.38 \%)$ & $8(30.77 \%)$ & $2(18.18 \%)$ \\
Water sediment & $2(18.18 \%)$ & $9(34.62 \%)$ & $3(27.27 \%)$ \\
Fish gut & $3(27.27 \%)$ & $5(19.23 \%)$ & $3(27.27 \%)$ \\
Fish feed & $2(18.18 \%)$ & $4(15.38 \%)$ & $3(27.27 \%)$ \\
\hline
\end{tabular}


Table.3 Bacteria distribution in each sample

\begin{tabular}{|l|c|c|c|c|c|}
\hline ISOLATES & $\begin{array}{c}\text { POND } \\
\text { WATER }\end{array}$ & FISH FEED & $\begin{array}{c}\text { POND } \\
\text { SEDIMENT }\end{array}$ & FISH GUT & $\begin{array}{c}\text { TOTAL } \\
\text { OCCURENCE IN } \\
\text { THE SAMPLES }\end{array}$ \\
\hline Escherichia coli & 1 & 2 & 1 & 3 & $7(14.58 \%)$ \\
Aeromonas species & 1 & 1 & 1 & 2 & $5(10.41 \%)$ \\
Salmonella species & 1 & 2 & 2 & - & $5(10.41 \%)$ \\
Proteus species & 2 & - & 2 & - & $4(8.33 \%)$ \\
Citrobacter freundii & 2 & - & 1 & - & $3(6.25 \%)$ \\
Morganella morganii & 2 & 1 & 2 & - & $5(10.41 \%)$ \\
Enterobacter species & 1 & - & 1 & 2 & $4(8.33 \%)$ \\
Serratia species & 1 & 1 & 1 & 1 & $4(8.33 \%)$ \\
Klebsiella species & 2 & 1 & 2 & - & $5(10.42 \%)$ \\
Provindencia species & 1 & - & 1 & 1 & $3(6.25 \%)$ \\
Shigella species & - & 1 & - & 2 & $3(6.25 \%)$ \\
\hline
\end{tabular}

Table.4 Percentage susceptibility pattern of bacteria to antibiotics

\begin{tabular}{|lccrrc|}
\hline Antibiotics & Sensitivity S (\%) & I & \multicolumn{2}{c|}{ Resistivity R (\%) } \\
\hline SXT & 1 & $(6.67 \%)$ & & 14 & $(93.33 \%)$ \\
CH & 1 & $(6.67 \%)$ & 14 & $(93.33 \%)$ \\
CPX & 14 & $(93.33 \%)$ & 1 & $(6.67 \%)$ \\
AM & 7 & $(46.67 \%)$ & 8 & $(53.3 \%)$ \\
AU & 5 & $(33.33 \%)$ & 10 & $(66.67 \%)$ \\
GN & $10(66.67 \%)$ & 5 & $(33.33 \%)$ \\
PEF & 10 & $(66.67 \%)$ & 5 & $(33.33 \%)$ \\
OFX & 9 & $(60 \%)$ & 6 & $(40 \%)$ \\
S & $\mathbf{8}$ & $(53.33)$ & 7 & $(46.67 \%)$ \\
SP & 13 & $(86.67 \%)$ & 2 & $(13.33)$ \\
\hline
\end{tabular}

$\begin{array}{ll}\text { Key } & \\ \text { SXT }=\text { Septrin } & \text { CH }=\text { Chloramphenicol } \\ \text { CPX = Ciprofloxacin } & \text { AM = Amoxacilin } \\ \text { AU = Augmetin } & \text { GN = Gentamycin } \\ \text { PEF = Perfloxacin } & \text { OFX = Tarivid } \\ \text { S = Streptomycin } & \text { SP = Sparfloxacin } \\ \text { R = resistant } & \text { S = sensitive }\end{array}$


Figure.1 Percentage (\%) of bacteria isolates per location

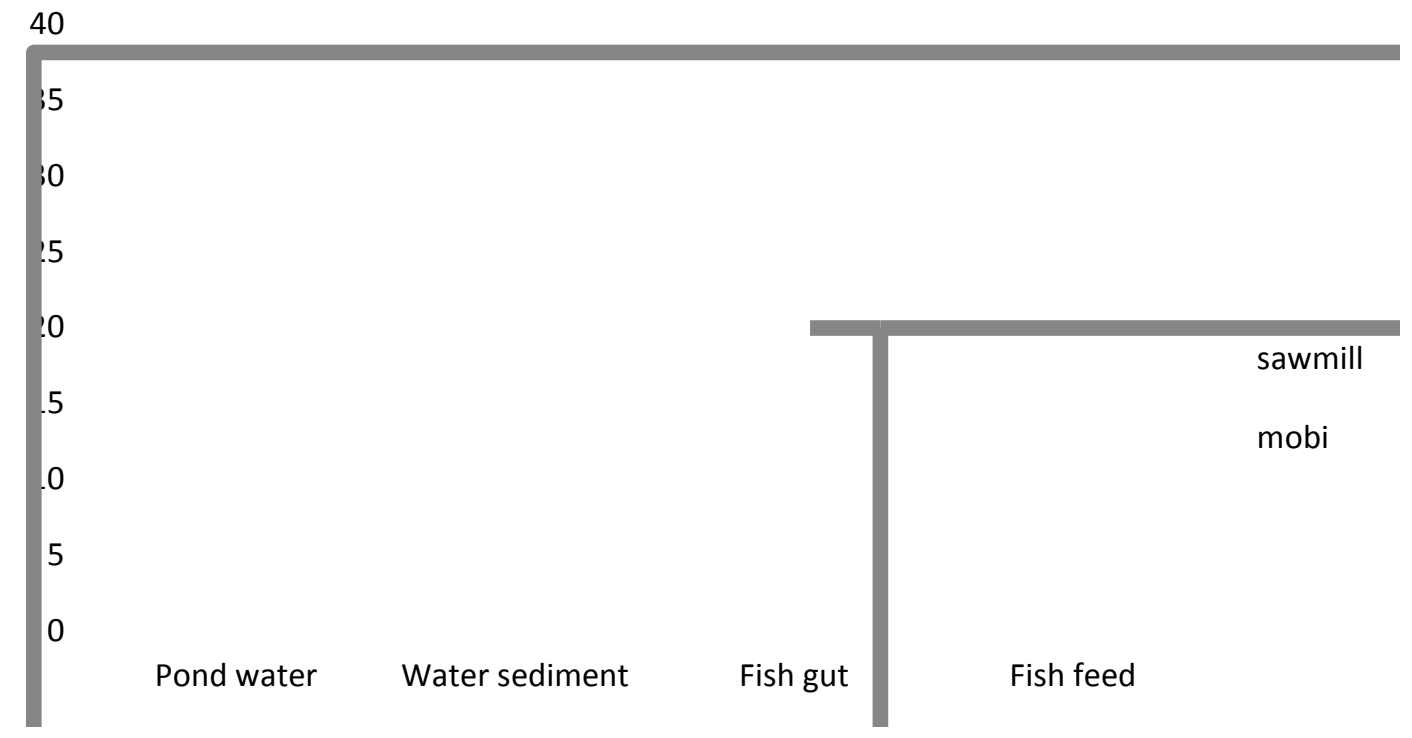

The isolation of Enterobacteriaceae: has become a serious issue in various Escherichia coli, Aeromonas species, environments for human health concern Salmonella species, Proteus species, (Neela et al., 2012; Rahman et al., 2008) and Citrobacter freundii, Morganella morganii, it has been well demonstrated that aquatic Enterobacter species, Serratia species, environments play a vital role for spreading of Klebsiella species ,Provindencia species and Shigella species from the three locations are in line with the findings of Ogbondeminu and Olayemi (1993) who reported that $50 \%$ of the microorganisms recovered from both fish and water of earthen pond fertilized with animal faecal waste were members of the family Enterobacteriaceae.

The presence of $E$. coli in all the samples indicated poor hygiene and sanitary condition in all the locations. This is in line with the study of Chandraval et al., (2010) which reported that fish and water samples collected from Nadia District of West Bengal in India were contaminated with faecal coliforms.

Aeromonas species, one of the bacteria isolated from the samples is a known human pathogen which poses a risk of fish-borne Aeromonas gastroenteritis in consumers of improperly cooked fish however this has shown that consumption of antibiotic in fishes

antibiotic resistant bacteria and gene in various ecosystem (Neela et al., 2009).

Surplus antimicrobial agents accumulate in integrated fish farms when the ponds are rarely emptied at the time of fish harvest, such an accumulation has been reported to establish selective pressure favoring selection and growth of antimicrobial resistant bacteria (Andreas et al., 2002). This may be the reason why some of the bacteria isolates used for this study were able to resist all the tested antibiotics.

Potential transfer of resistant bacteria and resistance gene from aquaculture environment to human can occur through direct consumption of antimicrobial resistant bacteria present in fish and associated products and this can lead to an increase in the number of infections, an increased frequency of treatment failure and increased severity of infection (Andreas et al., 2002) 
Conclusion of the study is as follows:

In view of the isolation of potential bacterial pathogens from all the sample types and high level of multi drug resistant bacterial contamination reported in this study necessary measures must be put in place to prevent the release or discharge of antimicrobial residues and antimicrobial resistant bacteria into ponds in Nigeria, particularly in Osun state in order to prevent the transfer of resistant genes from fish pathogens to human as the effect can be devastating if consumed by man. Such measures include: discouragement of the indiscriminate use of antimicrobial agents in integrated fish farms, discouragement of the use of faeces of poultry and encouragement of the use of feeds with high microbial quality in order to avoid using antimicrobials as growth additives. There should also be regular drainage of pond water after specific period of time. In addition to the above, there should equally be public enlightenment programme on the inherent danger that may accompany the consumption of improperly cooked fish.

Lastly more elaborate studies especially multicenter studies should be carried out to determine the impact of Integrated Fish Farming on Antimicrobial Resistant Bacteria in ponds on a national level in order to enable formulation of guidelines for monitoring and establishing preventive programmes.

\section{References}

AIFP (2005): Farming in Nigeria waters. Newsletter of the Aquaculture and Inland Fisheries project of the National Special Programme for food security in Nigeria. FAO Office Abuja, Nigeria.3 (4): 2-4.55.

Andreas Petersen, Jens Strode Anderesen, Tawatchal Kacwmak Temdoung Somsin and Anders Dalsgaard (2002): Impart of integrated fish farming on antimicrobial resistance in a pond environment: Appl Environ microbial Vol.68(12:6036-6042).

Ayinla, O.A. (2003): Integrated fish farming: A veritable tool for poverty alleviation/Hunger eradication in the Niger Delta Region. In A.A Eyo and J.O Atanda (eds). Conference Proceedings of Fisheries Society of Nigeria, Owerri, Nigeria. Pp. 40-41.

Bager F.M.; Madsen J. Christensen and F.M. Aarestrup (1997): Avoparcin used as a growth promoter is associated with the occurrence of vancomycin resistant Enterococcu faecium in Danish poultry and pig farm prev. vet. Med. $31-95-$ 112 (pubmed).

Chandraval, D., Debasish, S., Ashis, K. P. and Chandan, S. (2010). The occurrence of scherichia coli in fish samples isolated from different ponds of Nadia District, West Bengal, India. Internet Journal of Food Safety, 12:181-186.

Davies, (1997): Origins, acquisition and dissemination of antibiotics resistance determinants, Ciba F symp 207:15-27.

FAO, (2003): The Role of Aquaculture in improving food Security and Nutrition. Committee on World food Security, food and Aquaculture Organization of the United Nations, Romes.

Harley, J.P. and Prescott, L.M. (1996) Microbiology Laboratory Exercises. 3rd Edition, McGraw-Hill Companies, New York.

Neela, F.A., Nonaka, L., Rahman, M.H \& Suzuki, S. (2009): Transfer of the chromosomally encoded tetracycline resistant gene tet $(\mathrm{M})$ from marine bacteria to Escherichia coli and Enterococcus faecalis. World Journal of Microbiology and Biotechnology 25(6): 1095-1101

Neela, F.A., Rahman, M.A., Banu, M.N.A., Rahman, M.H., OHTA, H. \& Alam, M.F. (2012): Occurrence of two 
antibiotic resistant bacteria in aquatic environment associated with shrimp farming in Bangladesh. Bangladesh Journal of Botany 41(@): 197-200.

Ogbondeminu and Olayemi (1993). Antibiotic resistance in enteric bacterial isolates from fish and water media. Journal of Aquatic Tropical, 8:207-212.

Ole E. H., Hilde K., KARI G., Collignon P., Iddya K, (2009): Human Health Consequences of Use of Antimicrobial Agents in Aquaculture. Clinical Infectious Diseases 49: 1248-1253.
Rahman, M. H., Nonaks, L., Tago, R. \& Suzuki S. (2008): Occurrence of two genotypes of tetracycline (TC) resistance gene $\operatorname{tet}(\mathrm{M})$ in the $\mathrm{TC}$ resistant bacteria in marine sediments of Japan. Environmental Science and Technology 42(14): 5055-5061.

Shashank Singh, Prabjeet Singh, Nitin Verma and Diniesh Kumar (1991): Integrated fish farming-Rationale and scope. College of fisheries, G.B. Pant University of Agriculture and Technology, Pantnagar, India.

\section{How to cite this article:}

Bolaji A. Samuel, Magdalene C. Igboama and Olufade, I.I. 2019. Impact of Integrated Fish Farming on Antimicrobial Resistant Bacteria in Pond Environments in Osun State, Nigeria. Int.J.Curr.Microbiol.App.Sci. 8(09): 2427-2434. doi: https://doi.org/10.20546/ijcmas.2019.809.281 